\title{
Milk production and feeding behavior in the camel (Camelus dromedarius) during 4 watering regimens
}

\author{
T. Bekele, ${ }^{*}$ N. Lundeheim, $\ddagger$ and K. Dahlborn ${ }^{\star 1}$ \\ *Department of Anatomy, Physiology, and Biochemistry, and \\ ‡Department of Animal Breeding and Genetics, Swedish University of Agricultural Sciences, SE-750 07 Uppsala, Sweden
}

\begin{abstract}
Camels survive and produce milk during recurrent prolonged hot and dry periods. The objective was to evaluate how different watering intervals affected milk production and feeding. Eight lactating camels ( $\mathrm{Cam}$ elus dromedarius) were recruited and subjected to 4 watering regimens in a Latin square design experiment performed at Haramaya University in Ethiopia. Each regimen lasted $16 \mathrm{~d}$ with $5 \mathrm{~d}$ of daily watering between periods: water was offered at $1315 \mathrm{~h}$ once daily (W1); on $\mathrm{d} 4,8,12$, and 16 (W4); on d 8 and 16 (W8); and on d 16 (W16). One camel became sick in the second period and its results were excluded. Camels were kept in a pen with minimal shade and a noon temperature of $30.9 \pm 0.1^{\circ} \mathrm{C}$. They had free access to hay and were offered $2 \mathrm{~kg}$ of concentrates 3 times daily. At noon on d $1,4,8,12$, and 16, a blood sample was taken from the jugular vein before watering. All calves were kept together in a separate pen. Morning and afternoon calves stimulated milk let-down before the camels were hand-milked, after which the calves suckled, emptying the udder. Camels maintained the milk volume during water deprivation for about $1 \mathrm{wk}$, but they produced less milk during the second week during W16. Morning milk osmolality increased from $315 \pm 3$ on d 1 to $333 \pm$ $3 \mathrm{mosm} / \mathrm{kg}$ on $\mathrm{d} 4$ during W4 and from $321 \pm 3$ on $\mathrm{d} 1$ to $342 \pm 3 \mathrm{mosm} / \mathrm{kg}$ on d 8 during W8. After watering at $1315 \mathrm{~h}$, milk osmolality decreased to $316 \pm 3$ and 323 $\pm 3 \mathrm{mosm} / \mathrm{kg}$, respectively, the same afternoon and then increased during recurrent water deprivation to $338 \pm 3$ (W4) and $347 \pm 3 \mathrm{mosm} / \mathrm{kg}$ (W8) on d 16, respectively. During W16, osmolality increased from $318 \pm 3$ to 336 $\pm 3 \mathrm{mosm} / \mathrm{kg}$ during the first $4 \mathrm{~d}$ of water deprivation, but during the remaining $12 \mathrm{~d}$ the further rise in osmolality was not higher compared with that on d 4 . The change in milk osmolality was linearly correlated to plasma osmolality $(\mathrm{r}=0.8)$, but milk lactose content did not increase. Contrary to widespread belief, camels
\end{abstract}

Received July 27, 2010.

Accepted November 23, 2010.

${ }^{1}$ Corresponding author: kristina.dahlborn@slu.se did not dilute their milk when dehydrated. Instead milk osmolality increased in parallel to blood osmolality. This study provides further support to earlier observations on camels' adaptation to their environment.

Key words: camel, feeding behavior, milk production, water deprivation

\section{INTRODUCTION}

The dromedary (Camelus dromedarius) is known for its ability to survive drought periods and camel milk has been called the white gold of the desert (Wernery, 2006). In eastern Ethiopia, the camel is mainly kept for milk production because of its ability to continue to produce milk during the recurrent dry periods (Zeleke and Bekele, 2001; Bekele et al., 2002).

Water, DMI, and nutrient quality of the feed affect milk production. The vegetation is often sparse in the desert and camels graze large areas to satisfy their nutritional needs and have to walk considerable distances to find water (Dahlborn, 2000). Water restriction for more than $24 \mathrm{~h}$ decreases food intake in ruminants, leading to lower milk volume in high-yielding cows (Little et al., 1980; Steiger Burgos et al., 2001) and goats (Dahlborn, 1987). In contrast to true ruminants, camels maintain food intake for $10 \mathrm{~d}$ during water deprivation (Yagil and Etzion, 1980a,b), whereas others find that food intake decreases sooner even if camels are not lactating (Schroter et al., 1987; Ben Goumi et al., 1993). It was considered important to determine how many days camels eat enough to maintain milk quantity and quality without access to water.

It is generally accepted that milk is kept iso-osmotic to blood plasma in ruminants (Linzell and Peaker, 1971; Bjerg et al., 2005). Camels belong to the subfamily Tylopoda under Artiodactyla and have several characteristics that differ from true ruminants. This can be one reason that reports claiming that camels maintain milk volume and dilute the milk during dehydration (Yagil and Etzion, 1980a) are widespread (FAO, 2010). But, Ben Goumi at al. (1993) showed that plasma osmolality increased to high levels during $14 \mathrm{~d}$ of water deprivation in nonlactating camels, and in 2 lactating camels, milk 
Table 1. Least squares means of ambient temperature and relative humidity at the Errer Valley Research Station during the experiment

\begin{tabular}{lccccccc}
\hline & \multicolumn{3}{c}{${\text { Temperature }\left({ }^{\circ} \mathrm{C}\right)}$} & & \multicolumn{3}{c}{ Relative humidity (\%) } \\
\cline { 2 - 3 } \cline { 6 - 7 } Period $^{1}$ & $0700 \mathrm{~h}$ & $1200 \mathrm{~h}$ & $1800 \mathrm{~h}$ & & $0700 \mathrm{~h}$ & $1200 \mathrm{~h}$ & $1800 \mathrm{~h}$ \\
\hline 1 & 19.6 & $28.0^{\mathrm{a}}$ & $28.7^{\mathrm{a}, \mathrm{b}}$ & & $82.5^{\mathrm{a}}$ & $48.2^{\mathrm{a}}$ & $48.8^{\mathrm{a}}$ \\
2 & 19.6 & $30.3^{\mathrm{b}}$ & $27.5^{\mathrm{a}, \mathrm{b}}$ & & $79.5^{\mathrm{a}}$ & $42.6^{\mathrm{a}}$ & $47.4^{\mathrm{a}}$ \\
3 & 20.4 & $33.1^{\mathrm{c}}$ & $29.3^{\mathrm{a}}$ & & $56.0^{\mathrm{b}}$ & $27.5^{\mathrm{b}}$ & $25.0^{\mathrm{b}}$ \\
4 & 20.7 & $32.3^{\mathrm{c}}$ & $26.3^{\mathrm{b}}$ & & $58.4^{\mathrm{b}}$ & $26.9^{\mathrm{b}}$ & $32.5^{\mathrm{b}}$ \\
\hline
\end{tabular}

${ }^{\mathrm{a}-\mathrm{c}}$ Means with different superscripts within a column differ at $P<0.05$ (SAS, proc mixed, Bonferroni adjustments; SAS Inst. Inc., Cary, NC).

${ }^{1}$ Each period comprised $16 \mathrm{~d}$, followed by $5 \mathrm{~d}$ with no measurements.

osmolality increased in parallel with plasma osmolality during dehydration (Dahlborn et al., 1997). The latter findings are not consistent with milk becoming diluted during dehydration in camels. The current study aimed to clarify contradictory results of studies of the ability of camels to dilute milk by investigating the effects on milk yield and osmolality in lactating camels kept on 4 different watering regimens.

\section{MATERIALS AND METHODS}

\section{Study Area}

This experiment was undertaken at the Haramaya University Camel Research Station in the Errer Valley, Ethiopia from the end of August to the middle of November; 2003.The station has about 3 ha of land protected by a fence and, inside, there is 1 pen for camels and 1 for goats. The valley is located at an altitude of 1,300 to $1,600 \mathrm{~m}$ above sea level and the predominant vegetation types are Acacia and Cactaceae spp. The climate is semi-arid with yearly rainfalls between 300 and $700 \mathrm{~mm}$ (Seleshi and Camberlin, 2006). Ambient temperature and humidity were measured with a thermohygrometer (Thermohygrometer, Nordpost, Enköping, Sweden) placed in the shade (Table 1).

\section{Animals and Experimental Design}

Eight lactating camels belonging to Haramaya University were used for the experiment. Their characteristics are in Table 2. All camels were clinically healthy, except for endo- and ectoparasites, and were treated with antihelmintics before the experiment started. They were kept in a sand pen $(24 \mathrm{~m} \times 30 \mathrm{~m})$ during the experiment and given $10 \mathrm{~d}$ of adaptation to experimental routines. The adult camels spent the night in a small pen $(6 \mathrm{~m} \times 6 \mathrm{~m})$ inside the large pen. Calves were kept together in a separate pen $(3 \mathrm{~m} \times 5 \mathrm{~m})$ at a corner of the large pen. A shed made of corrugated metal sheets $(3 \mathrm{~m} \times 4 \mathrm{~m})$ was built at one side of the pen and was used for storage.

The experiment was a Latin square design. The regimens were as follows: watering once daily (W1); watering on $\mathrm{d} 4,8,12$, and 16 (W4); watering on $\mathrm{d} 8$ and 16 (W8); and = watering on d 16 (W16) (Table 2). Water was offered at $1315 \mathrm{~h}$. Each period was 16 $\mathrm{d}$, followed by $5 \mathrm{~d}$ when camels could walk outside the

Table 2. Characteristics of the camels used in the experiment and experimental design

\begin{tabular}{|c|c|c|c|c|c|c|c|c|c|}
\hline Camel (n) & $\begin{array}{l}\text { Age } \\
(\mathrm{yr})\end{array}$ & Parity & $\begin{array}{l}\text { Lactation } \\
\text { mo }\end{array}$ & $\begin{array}{l}\text { Milk volume } \\
\text { (L) }\end{array}$ & $\begin{array}{c}\text { Calf } \\
\text { (n of dam) }\end{array}$ & \multicolumn{4}{|c|}{ Watering period ${ }^{1}$} \\
\hline 1 & 14 & 4 & 2 & 3.1 to 3.6 & $1,3^{2}$ & W4 & W16 & W1 & W8 \\
\hline 2 & 6 & 1 & 8 & 2.0 to 2.2 & 2 & W16 & W1 & W8 & W4 \\
\hline 3 & 6 & 1 & 2 & 3.0 to 3.2 & 3 & W4 & $\mathrm{W} 16^{3}$ & - & - \\
\hline 4 & 6 & 1 & 0.5 & 2.5 to 3.2 & 4 & W1 & W8 & W4 & W16 \\
\hline 5 & 6 & 1 & 1.5 & 2.3 to 3.2 & $5,4^{4}$ & W8 & W4 & W16 & $\mathrm{W} 1$ \\
\hline 8 & 9 & 3 & 2 & 2.4 to 2.7 & 8 & W16 & W1 & W8 & W4 \\
\hline
\end{tabular}

${ }^{1}$ There were 4 consecutive periods. Camels were watered at noon according to a Latin square design: once daily (W1), every 4th d (W4), every 8th d (W8), and at noon on d 16 (W16).

${ }^{2}$ The calf of camel 1 died in period 2 ; thereafter, the calf of camel 3 suckled both dams.

${ }^{3}$ Camel sick, removed from the experiment.

${ }^{4}$ The calf of camel 5 died after 1 wk into period 1 ; the calf of camel 4 suckled both dams. 
pen and were watered once daily. For animal welfare reasons, the following endpoints were predetermined: if plasma osmolality exceeded $360 \mathrm{mosm} / \mathrm{kg}$, or if a camel stopped eating, or if a camel lost more than $30 \%$ of its BW, then the animal would be given immediate access to water. One of the camels got ill (probably Trypanosoma) during the second period and was excluded from the analyses. Also, because 1 camel stopped eating on d 12 during W16 and was at that day given free access to water, data from d 13 to 16 of that treatment were excluded from the statistical analyses.

\section{Experimental Procedures}

At $0700 \mathrm{~h}$, the camels were let out of the pen and tied up to separate poles along one side of the large pen. Concentrates $(2 \mathrm{~kg} / \mathrm{camel})$ were distributed in buckets. Grass hay was hung on the poles for ad libitum consumption. The calves were let out to stimulate milk letdown and thereafter, the camels were hand-milked. The camels were released around $0900 \mathrm{~h}$ to walk freely in the large pen. The calves were kept outside the large pen in the larger area during daytime. At $1215 \mathrm{~h}$ the camels were weighed and then tied up and offered concentrates. Hay was filled up if needed. Between 1300 and 1315 h, measured amounts of water were poured into the troughs in volumes well above what the camels were expected to drink according to the watering regimen (Table 2). When the camels showed no further interest in water, they were released into the large pen. The water left in the trough was measured. At $1700 \mathrm{~h}$, the camels were tied up again, offered concentrates, and hand-milked. During the first period, it was noticed that the camels ate the concentrates they wanted immediately and did not return until tied up next time. The concentrate orts were collected and weighed after each feeding time during periods 2,3 , and 4 . The composition of the hay and concentrates are given in Table 3.

Feed Samples and Analyses. Subsamples of hay and concentrate were collected during each period and pooled into 1 sample stored at room temperature. This sample was divided into 2 parts. One-half was dried at $105^{\circ} \mathrm{C}$ for $\mathrm{DM}$ determination and the remaining half was dried at $55^{\circ} \mathrm{C}$ for $72 \mathrm{~h}$ and ground through a 1-mm mesh sieve. The samples were transported to Sweden for chemical analysis (Table 3). Ether extract was analyzed according to the Official Journal of European Communities (1984) and CP by the Kjeldahl method (Kjeltec, 2460, Foss Analytic A/S, Hillerød, Denmark). Neutral detergent fiber concentration was analyzed according to Chai and Udén (1998). Calcium and phosphorus were analyzed by the inductively coupled plasma atomic emission spectroscopy method (Analycen, Lidköping, Sweden).
Table 3. Chemical composition of the feed given to the camels ${ }^{1}$

\begin{tabular}{lcc}
\hline Item & $\begin{array}{c}\text { Grass } \\
\text { hay }\end{array}$ & Concentrate $^{2}$ \\
\hline DM (\%) & 91.5 & 92.4 \\
CP (\%) & 5.4 & 31.4 \\
Ether extract (\%) & - & 6.3 \\
Total ash (\%) & 6.5 & 7.1 \\
NDF (\%) & 61.6 & 25.3 \\
ME $(\mathrm{MJ} / \mathrm{kg}$ of DM) & 9.0 & 12.4 \\
Calcium (\%) & 0.39 & 0.30 \\
Phosphorous (\%) & 0.10 & 0.73 \\
\hline
\end{tabular}

${ }^{1}$ Values are on a DM basis.

${ }^{2}$ Mixture of $50 \%$ wheat bran, $25 \%$ wheat short, $21 \%$ groundnut, $3.5 \%$ bone meal, and $0.5 \%$ salt.

${ }^{3}$ Calculated values.

Behavior. The behavior of each camel was recorded every 5 min from 0700 to $1200 \mathrm{~h}$ and from 1300 to 1800 $\mathrm{h}(120$ recordings $=100 \%)$. The behavioral measurements were performed only on d 11 and 15 in each period (i.e., the days when the camels were most dehydrated before watering on $\mathrm{d} 12$ and 16, respectively).

Camels were considered eating hay if they were seen with hay in their mouth or if chewing while standing next to the hay. Intake of concentrates was noted when camels took concentrates into their mouths and chewed. Grazing was defined as finding and chewing plants. Ruminating was noted if regurgitation occurred and camels were chewing previously swallowed food.

Milk Let-Down, Hand-Milking, and Suckling. The calves stimulated milk let-down and then the camels were hand-milked by their caretakers. All 4 teats were milked on each camel unless the condition of the calves necessitated that more milk needed to be left. The milkers were instructed to treat each camel in the same manner throughout the experiment (except camel 1). Camel 1 (Table 2) had 4 teats milked in the morning and 2 teats in the afternoon during period 1 only, then 4 teats were milked, whereas camels 7 and 8 followed this regimen (4 teats in the morning, 2 in the afternoon) throughout the study. Camel 5 always had 2 teats milked. Thereafter, the calves were allowed to suckle whatever remained in the udder. Milk let-down time, milking time, and suckling time were measured every morning with a stopwatch.

Blood Sampling. Five milliliters of blood was collected from the jugular vein in pre-chilled venoject tubes containing Li-heparin at $1240 \mathrm{~h}$ on $\mathrm{d} 1,4,8,12$, and 16 in each period. The tubes were immediately put on ice in a sealed box.

Sample Collection and Transportation. Milk volume was measured after hand-milking in the morning and afternoon, using a graduated cylinder. Milk samples were collected after each milking and imme- 
diately put in pre-chilled tubes and kept on ice in a sealed box.

Milk and blood samples were transported to the Department of Animal Science, Haramaya University for analyses. Upon arrival, blood samples were centrifuged at $1500 \times g$ (Centurion Scientific LTD model K40R series, West Sussex, UK) at $4^{\circ} \mathrm{C}$ for $10 \mathrm{~min}$. The osmolality of both milk and blood were measured on the same day by freezing-point depression (Fiske 2400 Multi-Sample Osmometer, Norwood, MA). The remaining samples were stored at $-20^{\circ} \mathrm{C}$. The TS, fat, protein, and lactose concentrations were determined using a milk analyzer (FARM Milk Analyzer 2001, Uppsala, Sweden).

\section{Statistical Analyses}

The core analyses were performed using ANOVA (PROC MIXED), according to a statistical model including the fixed effects of watering regimen and sampling day, nested within watering regimen. The statistical model included the random effects of camel and period. For some variables, the statistical model was modified to include, besides the random effects, the fixed effects of watering regimen, sampling week (d 0 to 8 ; $d 9$ to 16), the interaction between watering regimen and sampling week, and sampling day nested within the interaction between watering regimen and sampling week. Least squares means were calculated, and differences between those means were compared using $t$-tests. Bonferroni corrections were applied for these comparisons, to reduce the risk of false significances. To estimate the regression of milk osmolality on blood plasma osmolality, the statistical model applied within watering regimen (for analyzing milk osmolality) included the random effect of camel, and the fixed regression on blood plasma osmolality.

\section{RESULTS}

\section{Water Intake}

With access to water once daily (W1), the camels drank $17 \pm 5 \mathrm{~L} / \mathrm{d}(\mathrm{LSM} \pm \mathrm{SEM})$. During W4, the water deficit was compensated by drinking $47 \pm 5 \mathrm{~L}$ (d 4), $49 \pm 5 \mathrm{~L} \mathrm{(d} \mathrm{8),} 46 \pm 5 \mathrm{~L}$ (d 12), and $53 \pm 5 \mathrm{~L}$ (d 16), respectively. During W8, they drank $72 \pm 5 \mathrm{~L}$ on $\mathrm{d} 8$ and after the following $8 \mathrm{~d}$ without water, they drank $72 \pm 5$ L. After 16 d without water, they drank $88 \pm 5 \mathrm{~L}$.

\section{Feeding Behavior and Concentrate Intake}

Camels spent about $60 \%$ of their time budget on feeding-related behavior when they were watered daily

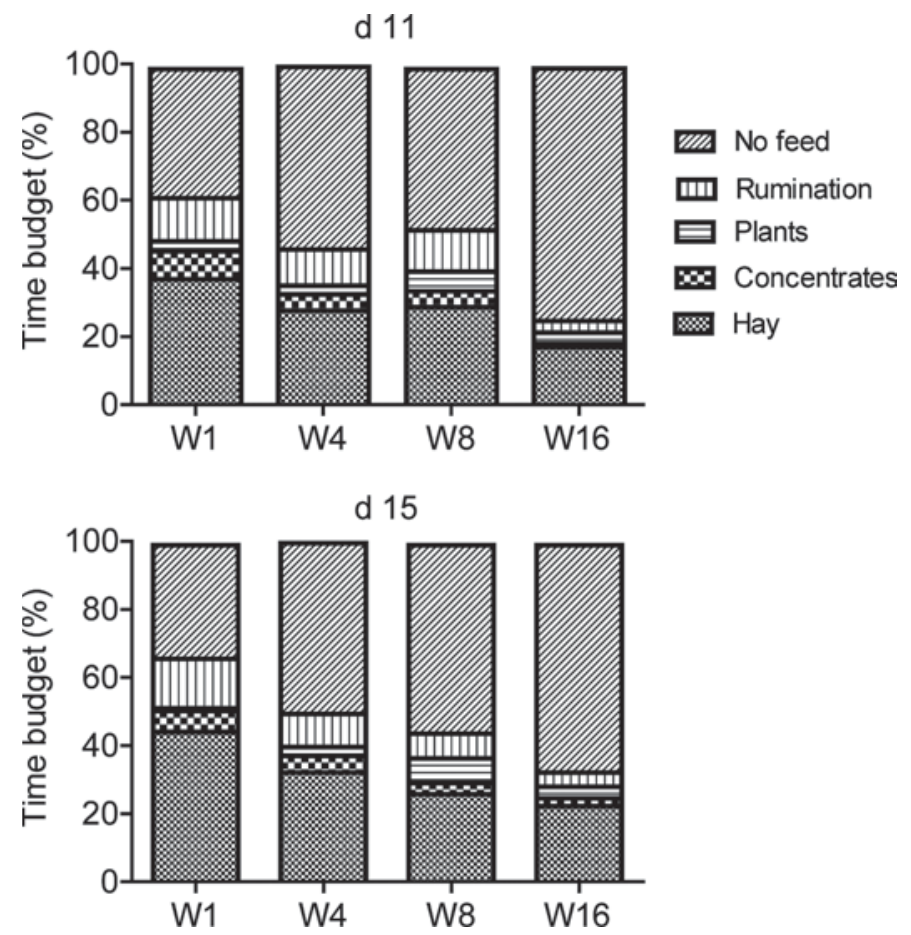

Figure 1. Time (LSM) spent on feeding-related behavior of 7 camels subjected to 4 watering regimens in a Latin square design. W1 = offered water once daily; W4 $=$ offered water on d $4,8,12$, and 16; $\mathrm{W} 8=$ offered water on $\mathrm{d} 8$ and 16 ; and $\mathrm{W} 16=$ offered water on $\mathrm{d}$ 16. Each period was $16 \mathrm{~d}$ long, followed by $5 \mathrm{~d}$ of watering once daily. Behavior was recorded between 0700 to $1200 \mathrm{~h}$ and 1300 to $1800 \mathrm{~h}$ (120 recordings $=100 \%)$. Time spent eating hay was shorter on d 11 and 15 during W16 than during W1 $(P<0.001)$. On d 11, the camels spent less time eating concentrates during W16 than during W1 $(P<$ $0.001)$. They ruminated for a shorter time on d 11 during W16 than during W1 $(P<0.001)$. Most time spent eating plants was observed on $\mathrm{d} 15$ during $\mathrm{W} 8$ compared with $\mathrm{W} 1(P<0.001)$. SEM $=3 \%$ (hay), $1 \%$ (concentrates), $1 \%$ (plants), and 3\% (rumination).

(W1), but less time was related to feeding as dehydration progressed (Figure 1). Time spent eating hay on d 11 was $17 \%$ during W16 compared with $37 \%$ during W1 $(P<0.001)$ and 22 compared with $44 \%$ on d 15 , respectively $(P<0.001)$. On $\mathrm{d} 11$, the camels spent $1 \%$ compared with $8 \%$ of the time eating concentrates during W16 compared with W1 $(P<0.001)$. They ruminated during 3 and $13 \%$ of the time on d 11 during $\mathrm{W} 16$ and $\mathrm{W} 1$, respectively $(P<0.001)$. Most time spent on eating plants was observed on d 15 during W8 compared with W1 $7 \%$ compared with $2 \%$ of time, $P$ $<0.001)$.

The camels did not consume all $6 \mathrm{~kg} / \mathrm{d}$ of concentrates during W1 initially, but they did so during the last d (Table 4). With increasing days of water deprivation, camels ate smaller amounts of concentrates. They consumed $5.7 \pm 0.3 \mathrm{~kg} / \mathrm{d}$ during W1; $4.8 \pm 0.3 \mathrm{~kg} / \mathrm{d}$ in $\mathrm{W} 4 ; 3.6 \pm 0.3 \mathrm{~kg} / \mathrm{d}$ in W8; and $2.9 \pm 0.3 \mathrm{~kg} / \mathrm{d}$ in W16 $(P<0.001$ among all treatments; Table 4$)$. 
Table 4. Least squares means of concentrate intake $(\mathrm{kg} / \mathrm{d})^{1}$ of 7 lactating camels during 4 different watering regimens using a Latin square design ${ }^{2}$

\begin{tabular}{lllll}
\hline & \multicolumn{4}{c}{ Watering regimen $^{3}$} \\
\cline { 2 - 5 } Day & W1 & W4 & W8 & W16 \\
\hline 1 & 5.0 & 4.8 & 4.1 & 4.7 \\
2 & 4.9 & 3.2 & 3.4 & 4.1 \\
3 & 5.5 & 3.8 & 3.1 & 4.3 \\
4 & 4.9 & 4.7 & 3.3 & 3.8 \\
5 & 5.9 & 4.8 & 3.7 & 3.4 \\
6 & 6.0 & 4.6 & 2.8 & 3.0 \\
7 & 5.4 & 4.2 & 2.5 & 2.5 \\
8 & 5.3 & 5.0 & 3.1 & 3.9 \\
9 & 5.3 & 5.5 & 4.9 & 3.4 \\
10 & 5.9 & 5.3 & 4.4 & 2.7 \\
11 & $5.9^{\mathrm{a}}$ & $4.8^{\mathrm{a}}$ & 4.1 & $1.0^{\mathrm{b}}$ \\
12 & 6.0 & 5.6 & 3.6 & 2.7 \\
13 & $6.0^{\mathrm{a}}$ & $6.0^{\mathrm{a}}$ & 4.4 & $1.0^{\mathrm{b}}$ \\
14 & $6.0^{\mathrm{a}}$ & 5.3 & 3.5 & $2.1^{\mathrm{b}}$ \\
15 & $6.0^{\mathrm{a}}$ & $4.3^{\mathrm{a}, \mathrm{b}}$ & $2.4^{\mathrm{b}}$ & $0.8^{\mathrm{b}, \mathrm{c}}$ \\
16 & $6.0^{\mathrm{a}}$ & 4.6 & 4.8 & $2.6^{\mathrm{b}}$ \\
\hline
\end{tabular}

${ }^{\text {a-c }}$ Means with different superscripts within rows differ at $P<0.05$ (SAS, proc mixed, Bonferroni adjustments; SAS Inst. Inc., Cary, $\mathrm{NC})$.

${ }^{1}$ Two kilograms distributed 3 times daily.

${ }^{2}$ Values are LSM; SEM $=0.7$.

${ }^{3} \mathrm{~W} 1$ = watering every day; $\mathrm{W} 4=$ watering every fourth day; $\mathrm{W} 8=$ watering every eighth day; W16 $=$ watering after $16 \mathrm{~d}(P<0.001$ among treatments).

\section{Milk Let-Down, Milking, and Suckling}

Milk let-down was achieved by the calves which massaged the udder for about $70 \mathrm{~s}$ (Table 5 ). This massage took longer during W16 than during W1, W4, and W8 $(P<0.01)$. Milking time was shorter during W16 compared with W1 and W4 $(P<0.05)$. After handmilking, the calves suckled. Suckling time did not differ between W1, W4, and W16, but was longer during W8 than during W16 $(P<0.05)$.

\section{Milk Yield and Osmolality}

Milk yields during afternoon and morning are illustrated in Figure 2A. In the morning, camels produced $1.1 \pm 0.1 \mathrm{~L}$ milk during W1 compared with $1.3 \pm 0.1$ $\mathrm{L}$ during W4 $(P<0.05)$. No difference between treatments in afternoon milk volumes was observed. During W16, camels produced $1.2 \pm 0.1 \mathrm{~L}$ milk in the morning during the first $8 \mathrm{~d}$ compared with $0.9 \pm 0.1 \mathrm{~L}$ during the last $8 \mathrm{~d}(P<0.001)$.

Milk osmolality did not change during W1 (Figure 2B). During water deprivation, milk osmolality gradually increased as dehydration progressed from $315 \pm$ 3 on $\mathrm{d} 1$ to $333 \pm 3 \mathrm{mosm} / \mathrm{kg}$ on $\mathrm{d} 4$ during W4 ( $P$ $<0.001$ ) and from $321 \pm 3$ on d 1 to $342 \pm 3 \mathrm{mosm} /$ $\mathrm{kg}$ on $\mathrm{d} 8$ during W8 $(P<0.001)$. After watering at noon, milk osmolality dropped to $316 \pm 3$ and $323 \pm$ $3 \mathrm{mosm} / \mathrm{kg}$, respectively, the same afternoon, and then increased during recurrent water deprivation to $338 \pm$ 3 (W4) and $347 \pm 3 \mathrm{mosm} / \mathrm{kg}$ (W8) on d 16. During W16, osmolality increased from $318 \pm 3$ to $336 \pm 3$ mosm $/ \mathrm{kg}$ during the first $4 \mathrm{~d}$ of water deprivation, but during the remaining $12 \mathrm{~d}$ the further rise in osmolality was not higher compared with that on $\mathrm{d} 4$.

\section{Milk and Plasma Osmolalities}

The increase in morning milk osmolality during W16 was linearly related to changes in blood plasma osmolality as illustrated in Figure 3.

\section{Milk TS, Lactose, Fat, and Protein Concentrations}

Milk TS concentration did not differ between treatments (Figure 4A), but TS was $12.6 \pm 0.3$ in afternoon and $11.8 \pm 0.3 \%$ in morning milk during W1 $(P<$ $0.01)$, and $12.8 \pm 0.3$ and $12.0 \pm 0.3 \%$, respectively, during W4 $(P<0.01)$.

The milk fat concentration is shown in Figure 4B. Fat concentration in afternoon milk did not differ between treatments. In morning milk, it was higher during W8 and W16 than during $\mathrm{W} 1$ and $\mathrm{W} 4(P<0.01)$. Fat concentration was $4.6 \pm 0.3(\mathrm{~W} 1), 4.8 \pm 0.3(\mathrm{~W} 4), 4.7$ $\pm 0.3 \%$ (W8), and $4.7 \pm 0.3 \%$ (W16) in afternoon milk compared with $3.8 \pm 0.3,3.9 \pm 0.3,4.0 \pm 0.3$, and 4.3 $\pm 0.3 \%$, respectively, in morning milk $(P<0.01$ morning versus afternoon milk).

Milk lactose concentration did not differ between treatments in afternoon milk (Figure $4 \mathrm{C}$ ). Milk lactose concentration in morning milk was $4.3 \pm 0.2 \%$ during both W1 and W4 compared with $4.1 \pm 0.2 \%$ during W16 $(P<0.05$ versus $\mathrm{W} 1$ and W4). A closer analysis revealed that the lactose concentration was $3.9 \pm 0.2 \%$ during the second week of water deprivation during W16 compared with $4.3 \pm 0.2$ and $4.2 \pm 0.2$ during W1 and W4, respectively $(P<0.05$ versus $\mathrm{W} 1, \mathrm{NS}$ versus

Table 5. Times for milk let-down, hand-milking, and suckling of 7 camels during 4 different watering regimens using a Latin square design

\begin{tabular}{lcccrr}
\hline & \multicolumn{4}{c}{ Watering regimen $^{1}$} \\
\cline { 2 - 5 } Item & $\mathrm{W} 1$ & $\mathrm{~W} 4$ & $\mathrm{~W} 8$ & W16 & \multirow{2}{*}{ SEM } \\
\hline Let-down (s) & $67.2^{\mathrm{a}}$ & $66.7^{\mathrm{a}}$ & $68.7^{\mathrm{a}}$ & $72.0^{\mathrm{b}}$ & 4.0 \\
Milking (s) & $105.9^{\mathrm{a}}$ & $107.3^{\mathrm{a}}$ & $104.6^{\mathrm{a}, \mathrm{b}}$ & $98.6^{\mathrm{b}}$ & 11.6 \\
Suckling (s) & $70.3^{\mathrm{a}, \mathrm{b}}$ & $70.1^{\mathrm{ab}}$ & $73.5^{\mathrm{a}}$ & $63.1^{\mathrm{b}}$ & 10.5 \\
\hline
\end{tabular}

${ }^{a, b}$ Least squares means within rows with different superscripts differ at $P<0.05$.

${ }^{1} \mathrm{~W} 1=$ watering every day; $\mathrm{W} 4=$ watering every fourth day; $\mathrm{W} 8=$ watering every eighth day; watering after $16 \mathrm{~d}$. 
A

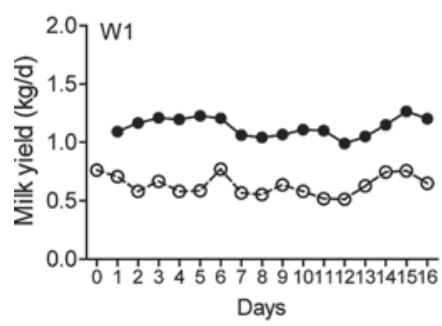

Days

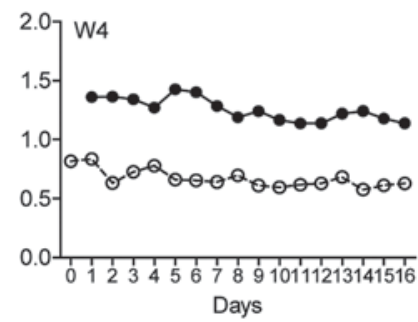

Days

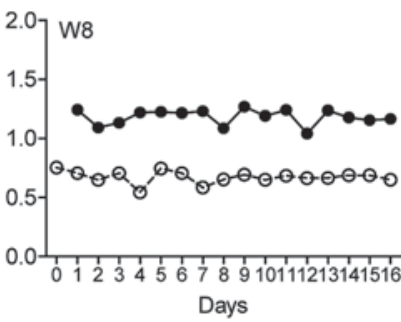

Days

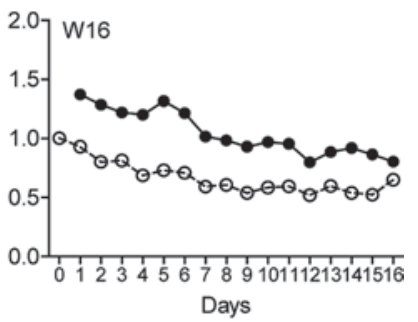

Days

B
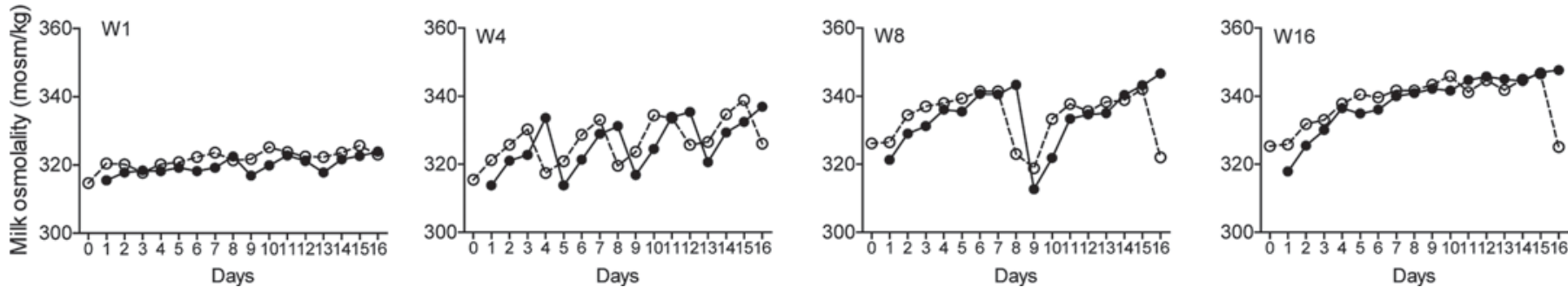

Figure 2. Least squares means of afternoon (open circles) and morning (black dots) milk yield (A) and milk osmolality (B) of 7 camels subjected to 4 different treatments: watering once daily (W1), once every fourth day (W4), once every eighth day (W8), and after 16 d (W16). Each treatment started with milking in the afternoon $(\mathrm{d} 0)$. Morning milk yield was larger during W4 compared with all other treatments $(P<$ 0.01). Morning and afternoon milk yields were smaller during the second compared with the first week during W16 $(P<0.001)$. Morning milk osmolality was elevated on d 4 compared with d 1 during W1, W4, and W16 $(P<0.001)$ and dropped after watering that day during W4, W8, and $\mathrm{W} 16(P<0.001)$.

W4). Milk lactose concentration was $4.3 \pm 0.2$ in morning milk compared with $4.0 \pm 0.2 \%$ in afternoon milk during W4 $(P<0.001)$.

Milk protein concentration (Figure 4D) was $3.3 \pm$ $0.2 \%$ in morning milk during W8 compared with $3.1 \pm$ $0.2 \%$ in the other treatments $(P<0.01)$. In afternoon milk the protein concentration was $3.2 \pm 0.2 \%$ during $\mathrm{W} 8$ and $3.0 \pm 0.2 \%$ during W16 $(P<0.01)$. The protein concentration did not differ between morning and afternoon milk.

\section{DISCUSSION}

Camels are recognized as a suitable species for sustainable livestock production in arid and semi-arid areas because they not only survive but continue to produce milk during severe drought periods (Guliye et al., 2000; Bekele et al., 2002). This extraordinary ability was confirmed in the camels studied in this experiment. The camels managed this although food intake decreased and milk osmolality increased.

The consumption of concentrate and time spent on feeding-related behaviors decreased as dehydration became more severe in the camels, which confirms results found with cows (Little and Shaw, 1978; Steiger Burgos et al., 2001). The present results support Schroter et al., $(1987 ; 1990)$ who subjected nonlactating camels to water deprivation, but differ from the undisturbed food

\section{W16}

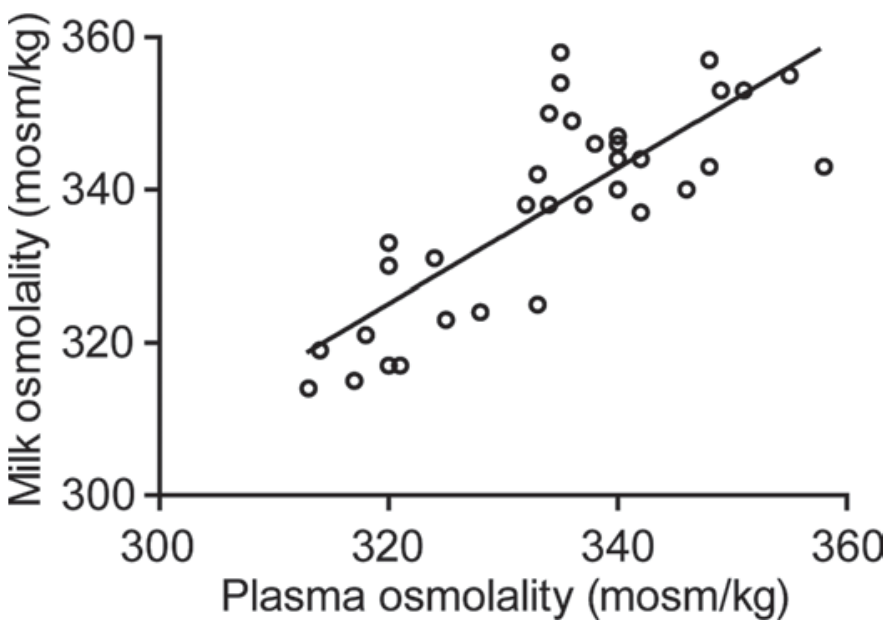

Figure 3. Regression of morning milk osmolality on plasma osmolality during treatment W16 (no water available during $16 \mathrm{~d}$ ) in 7 lactating camels. The regression equation was estimated as $\mathrm{Y}=43.7+$ $0.88 \times \mathrm{X}$. The regression coefficient was significant $(P<0.001)$. 
intake reported during 10-d water deprivation in lactating camels (Yagil and Etzion, 1980a).

Milk synthesis is dependent on solutes brought to the mammary glands by the blood and lactose is synthesized from blood glucose. During water deprivation fat, protein and lactose concentrations increase in true ruminants with lactose being the main osmotic component (Dahlborn, 1987). During food deprivation in true ruminants, fat and protein concentrations increase, but lactose concentration decreases. Milk fat concentration became higher with increasing degree of dehydration in the camels in the present study, but the protein concentration changed less. The lactose concentration did not increase, and was lowest when camels were dehydrated for $16 \mathrm{~d}$. This was probably due to the decreasing consumption of concentrates and that camels spent less time eating hay as dehydration became more severe, which could have affected the blood supply of glucose to the mammary glands. Thus, the effects on milk composition in the camels in this study appeared to be a combination of water deprivation and decreased feed intake.

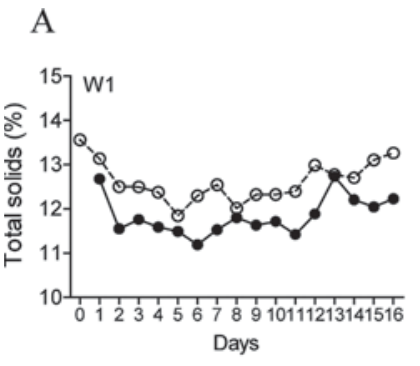

B

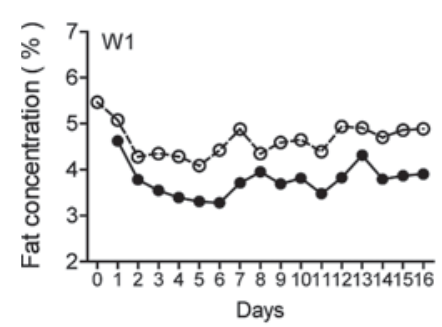

$\mathrm{C}$

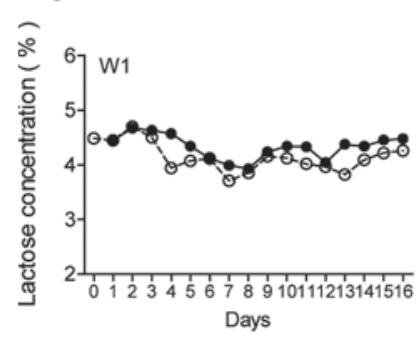

D

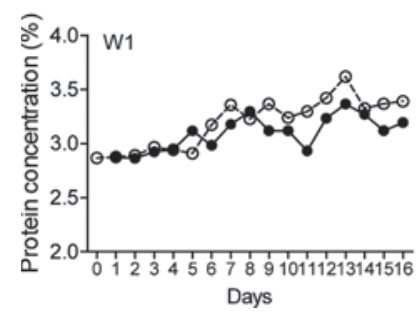

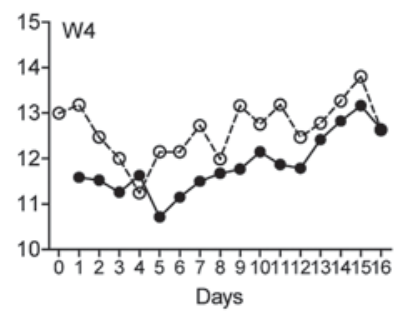
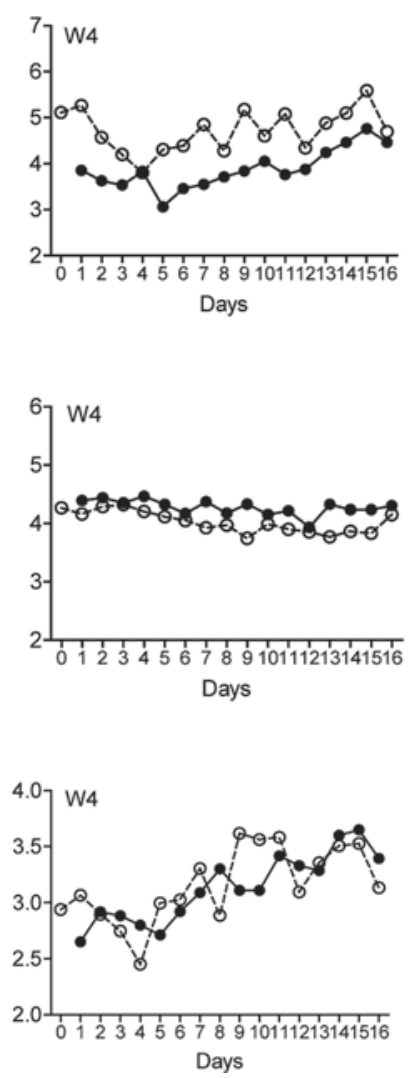
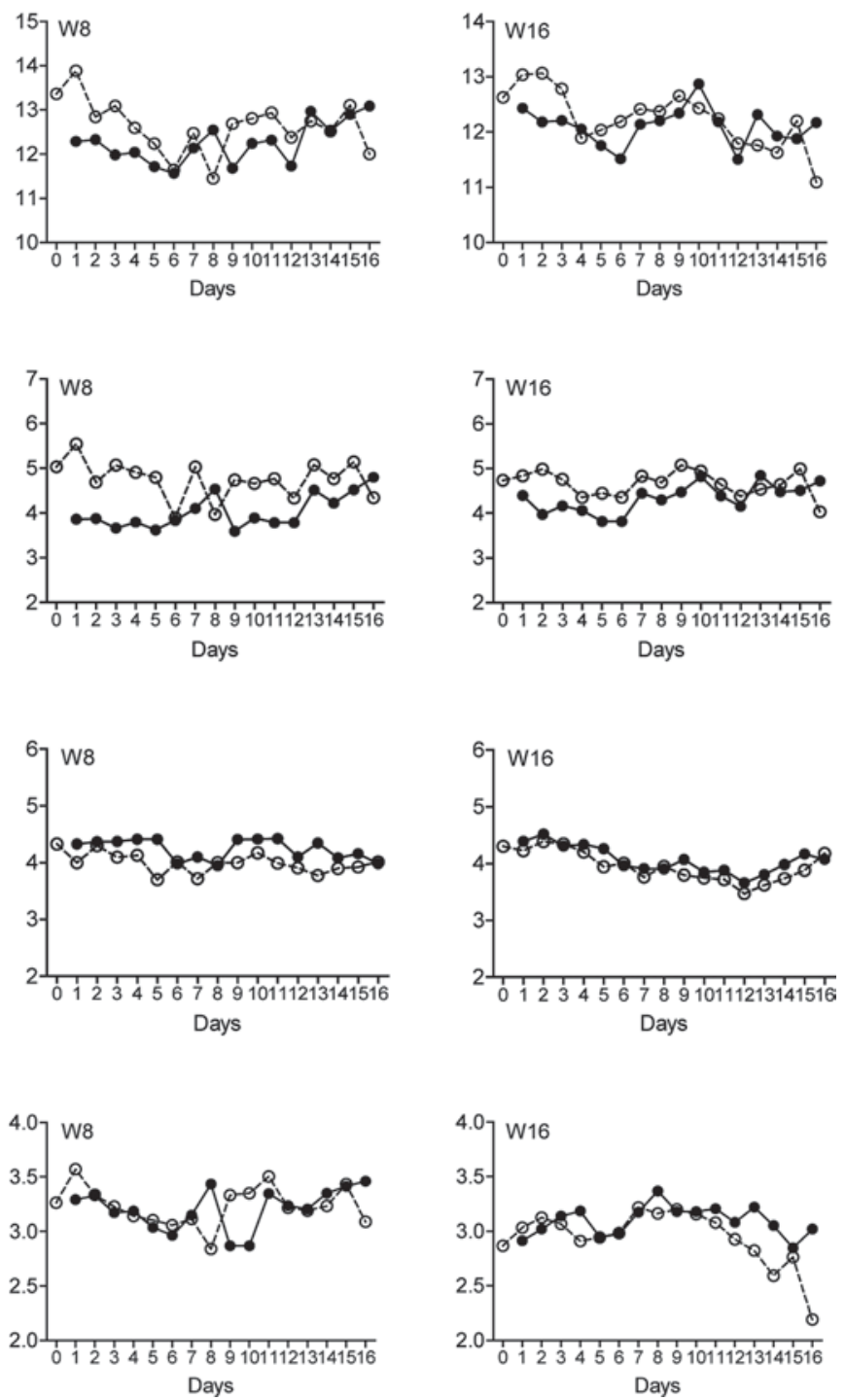

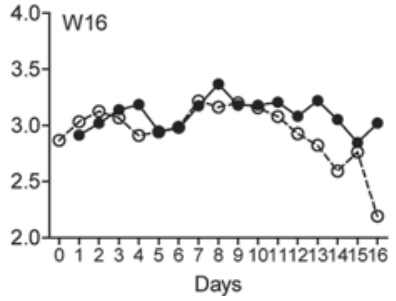

Figure 4. Least squares means of total solids (A), fat (B), lactose (C), and protein concentrations (D) in afternoon (open circles) and morning (black dots) milk from 7 camels on 4 different treatments: watering once daily (W1), once every fourth day (W4), once every eighth day (W8), and after $16 \mathrm{~d}$ (W16). Morning milk fat concentrations were decreased during W8 and W16 compared with W1 and W4 $(P<0.01)$. Milk lactose concentration was higher during the first compared with the second week during W16 in morning and afternoon milk $(P<0.05)$. Morning milk protein concentration was higher during W8 than during the other treatments $(P<0.01)$ and higher during W8 than during W16 $(P<0.01)$ in afternoon milk. 
The observation that lactose concentration did not increase during dehydration in the camels was surprising in view of the increasing osmolality. Therefore, some small molecule other than lactose must have caused the change in osmolality, perhaps sodium as suggested by Yagil and Etzion (1980a,b), or urea. Furthermore, lactose concentration was lowest during W16, when food intake was markedly decreased, compared with that during the other regimens.

Yagil and Etzion (1980a,b) reported decreased milk TS, fat, and protein concentrations, during repeated dehydration periods in camels, which differ from the findings in the present study, whereas the decreased lactose concentration was similar. As a consequence of these changes, the water percentage increased and the authors in previous studies drew the conclusion that the milk of camels becomes diluted during dehydration. In the present study, it was confirmed that milk osmolality was correlated to plasma osmolality and increases during dehydration in the camels, supporting previous observations in cows (Little et al., 1980) and goats (Dahlborn, 1987). In this sense, camels do not dilute the milk when dehydrated.

When camels are kept for milk production, mother and calf are normally kept separated and the calf is allowed to stimulate the udder to initiate the let-down reflex and to suckle the first drops. Milk let-down is visible by a sudden swelling of the teats (Yagil et al., 1999). In the current study, the shortest milking and suckling times were found during W16, which could be expected because milk yield was lower during this treatment.

In conclusion, camels increased milk and blood osmolality in response to water deprivation and decreased their feed intake as dehydration became severe. Milk yield and milk composition were unchanged during the first week, but during the second week of water deprivation concentrate intake decreased and milk yield was decreased. Nevertheless, this study gives further strength to earlier observations on camels' remarkable adaptation to their environment.

\section{ACKNOWLEDGMENTS}

This work was supported by SIDA (SAREC) joint $\mathrm{PhD}$ program between the Swedish University of Agricultural Sciences and Haramaya University (T. Bekele). We thank Mengistu Urge and Fascile Berehe (Department of Animal Sciences, Haramaya University, Alemaya, Ethiopia) for valuable assistance, the Somali people in Errer Valley for taking good care of the camels, and Richard Hopkins (Department of Ecology, Swedish University of Agricultural Sciences, Uppsala, Sweden) for correcting the English writing in the paper.

\section{REFERENCES}

Bekele, T., M. Zeleke, and R. M. T. Baars. 2002. Milk production performance of the one humped camel (Camelus dromedarius) under pastoral management in semi-arid eastern Ethiopia. Livest. Prod. Sci. 76:37-44.

Ben Goumi, M., F. Riad, J. Giry, F. de la Farge, A. Safwate, M. J. Davicco, and J. P. Barlet. 1993. Hormonal control of water and sodium in plasma and urine of camels during dehydration and rehydration. Gen. Comp. Endocrinol. 89:378-386.

Bjerg, M., M. D. Rasmussen, and M. O. Nielsen. 2005. Changes in freezing point of blood and milk during dehydration and rehydration in lactating cows. J. Dairy Sci. 88:3174-3185.

Chai, W., and P. Udén. 1998. An alternative open method combined with different detergent strengths in the analyses of neutral detergent fiber. Anim. Feed Sci. Technol. 74:241-288.

Dahlborn, K. 1987. Effect of temporary food or water deprivation on milk secretion and composition in the goat. J. Dairy Res. 54:153-163.

Dahlborn, K. 2000. Physiological explanations to why the camel can survive and produce under desert conditions. Pages 18-34 in Selected Topics on Camelids. T. K. Gahlot and J. Singh, ed. Camel Publisher, Bikaner, India.

Dahlborn, K., J. Hossaini-Halali, and S. Benlamlih. 1997. Changes in fluid balance, milk osmolality and water content during dehydration and rehydration in two lactating camels (Camelus dromedarius). J. Camel Pract. Res. 14:207-211.

FAO. 2010. Composition of camel milk. Accessed September 17, 2010. http://www.fao.org/docrep/003/X6528E/X6528E05.htm.

Guliye, A. Y., R. Yagil, and F. D. D. Hovell. 2000. Milk composition of Bedouin camels under semi-nomadic production system. J. Camel Pract. Res. 7:209-212.

Linzell, J. L., and M. Peaker. 1971. Intracellular concentrations of sodium, potassium, and chloride in the lactating mammary gland and their relation to the secretory mechanism. J. Physiol. 216:683-700

Little, W., K. A. Collis, P. T. Gleed, B. F. Sansom, W. M. Allen, and A. J. Quick. 1980. Effect of reduced water intake by lactating dairy cows on behaviour, milk yield and blood composition. Vet. Rec. 106:547-551.

Little, W., and S. R. Shaw. 1978. A note on individuality of drinking water by dairy cows. Anim. Prod. 26:225-227.

Official Journal of the European Communities. 1984. Determination of crude oils and fats. Method B. No. 15:29-30.

Schroter, R. C., D. Robertshaw, M. A. Baker, V. H. Shoemaker, R. Holmes, and K. Schmidt-Nielsen. 1987. Respiration in heat stressed camels . Respir. Physiol. 70:97-112.

Schroter, R. C., R. Zine Filali, A. P. R. Brain, P. V. Jeffery, and D. Robertshaw. 1990. Influence of dehydration and watering on camel red cell size: A scanning electron microscopic study. Respir. Physiol. 81:381-390.

Seleshi, Y., and P. Camberlin. 2006. Recent changes in dry spell and extreme rainfall events in Ethiopia. Theor. Appl. Climatol. 83:181-191.

Steiger Burgos, M., M. Senn, F. Sutter, M. Kreuzer, and W. Langhans. 2001. Effect of water restriction on feeding and metabolism in dairy cows. Am. J. Physiol. Regul. Integr. Comp. Physiol. 280:R418-R427.

Wernery, U. 2006. Camel milk, the white gold of the desert. J. Camel Pract. Res. 13:15-26.

Yagil, R., and Z. Etzion. 1980a. Effect of drought condition on the quality of camel milk. J. Dairy Res. 47:159-166.

Yagil, R., and Z. Etzion. 1980b. Milk yield of camels (Camelus dromedarius) in drought areas. Comp. Biochem. Physiol. A 67:207209

Yagil, R., C. van Creveld, G. Abu-R'Kaik, and U. Merin. 1999. Milk "let-down" in camels. J. Camel Pract. Res. 6:27-29.

Zeleke, M., and T. Bekele. 2001. Effects of season on the productivity of camels (Camelus dromedarius) and the prevalence of their major parasites in Eastern Ethiopia. Trop. Anim. Health Prod. $33: 321-329$. 